\section{The Tide-Predicter}

Mr. Edward Roberts' letter in Nature for April i4 contains statement; giving an erroneous view of the oriyin of the tide-predicter. Any one who feels sufficient interest in the sub ject to derive full information will find it in my palper on "The Tide-Gauge, Tidal Harmonic Analyser, and Tide-Predicter,' read befure the Institution of Civil Engineers on March I and in the abstract of the discussion which followed it, to be published in the Minutes of the Proceedings of the Institution (vol. Ixv. sess. 1880.8I, part iii.), and he will see that my letter in NATURE of March $3 \mathrm{I}$ is correct.

The University, Glasgow, April I6

\section{Geological Relations of Gold in Nova Scotia}

IN the notice of the report of Mr. Murray on the gold of Newfoundland (NATURE, vol. xxiii. p. 472) I observe a reference to my own opinion of the age of the gold of Nova Scotia which needs some correction. In the second edition of "Acadian Geolugy" ( 1868 ) the gold bearing series is included in the Lower Silurian, but this referred to the larger sense of that term in which it was used to include the Cambrian as well. In the third edition ( 1878 , Supplement, pp. 8I, 85, 92) I have referred this formation, on the evidence of fossils and stratigraphical position, to the age of the Lower Cambrian or Longmynd series, thus placing it on a lower horizon than the fossiliferous Primordial of Eastern Newfoundland, which I suppose to be of the age of the Acadian or Menevian group. There is therefore little difference between Mr. Murray's estimate of the age of the gold-bearing rocks of Newfoundland and my own of that of the similar rocks in Nova Scotia, except that I presume he would classify the Newfoundland series as Upper Huronian rather than Lower Cambrian. With reference to this I have been disposed to regard Mr. Murray's Aspidella slates and the associated rocks as equivalents of the Kewenian or "Upper copper-bearing group " of the West, and probably Upper Huronian, in which case they might be a little below my Nova Scotia Lower Cambrian ; but the precise age of both series is determined merely by the fact that they appear to belong to the period between the Huronian proper, or Lower Huronian, and the Acadian group, or Menevian (Etage C. of Barrande).

It is proper to add that in the third edition of "Acadian Geology" I have shown that the filling of the Nova Scotia gold veins is much more recent than the containing rocks, and belongs to the time intervening between the Upper Silurian and the Lower Carboniferous, the richer deposits als ) appearing to be related to the occurrence of intrusive granites of Devonian age. There is no reason, therefore, other than the mineral character of the containing beds, why such veins might not occur in any rocks older than the Devonian, and gold discuveries have been reported in localities where the rocks are supposed to be Huronian and Silurian; but I have had no opportunity of personally verifying these statements. Thus far the important gold veins are known only in that great series of slates and quartzites of the Atlantic coast which I have referred to the Lower Cambrian.

McGill College, Montreal, April 4

\section{Symbolical Logic}

Prof. Jevons, in his criticism of my method in Nature, vol. xxiii. p. 485 , has stated the main points at issue between us so fully and clearly, and on the whole so fairly, that I need only say a very few words in reply.

As to the charge that my method is ante-Boolian or antiBoolian, I do not seek to repel it ; on the contrary, I maintain that my method is different from Boole's in principle, and very different indeed in its practical working. The really important questions to be settled are these :

I. Are the definitions which I give of my symbols clear and unambiguous?

2. Are the rules and formulæ which I derive from these definitions correct?

3. Are the innovations which I propose of any practical utility?

Now, I do not think that any one who has read my papers in the Procedings of the London Mathematical Society and my articles in Mind and in the Philosophical Magazine will refuse to answer Yes to questions I and 2 ; and with regard to question
3 I can only say that any one who answers $N o$ is bound in fairness to prove the inutility of my innovations by solving one or two of my hardest problems without their aid, and in an equally clear and concise manner. My proposal of an amicable contest in the Educational Times meant nothing more serious than this.

Some of my critics (not including Prof. Jevons however) seem anxious to magnify the points of resemblance between my method and its predecessors, especially Boole's, and to minimise the points of difference. It may be as well therefore to state briefly what characteristics distinguish my method, so far as I know, from all the methods which have preceded it, and what advantages, in my opinion, accompany these characteristics.

In the first place, then, every single letter in my notation, as well as every combination of letters, denotes a statement. By this simble device I gain the important advantages of generality of expression and uniformity of interpretation and treatment. It enables me to express many important logical laws in simple and symmetrical formulæ, as, for instance,

$$
(A: a)(B: b)(C: c):(A+B+C: a+b+c),
$$

which otherwise could not be so expressed. To secure these advantages I sacrifice abjolutely nothing. The relations of classes, including the ordinary syllo gisms, I express by speaking throughout of one individual, just as mathematicians express the properties of curves, surfaces, and volumes, by speaking throughout of the varying distances of one representative point.

My claim to priority on this head has been called in question on the ground that Boole too, in his equations about "secondary proposition=," denotes statements by single letters. The plain truth however is that Boole takes some pains to prevent his readers from imagining that he does anything of the kind. $\mathrm{He}$ says distinctly, and in perfect consistency with the whole tenor of his book, in which he de icribes his algebra of logic as a mere offshoot and part of the ordinary algebra of quantity, that in his equations any single letter, such as $x$, denotes the portion of time during which sjme proposition $x$ is true, the whole universe of time to which the discourse refers being the unit (see "Laws of Thought," from p. I64 to p. I 70). Neither will one find any. where in Boole's work the idea (sugyested to me by analytical geometry) of investigating the relations of different classes, while speaking only of one individual, and thus dispensing entirely with the quantitative words all, some, and none, which are so characteristic of the old logic.

Another peculiarity of my method is that my symbol of denial (an accent) is made repeatedly to apply to expressions of varying complexity, as, for instance, $(x y)^{\prime},(x+y z)^{\prime} .\left(x: y^{\prime}\right)^{\prime}$, leading to rules and formulæ of operations, to which I find no parallel in any prior symbolic system with which I am acquainted.

Boole uses $\bar{x}$ as an abbreviation for $\mathrm{I}-x$. Let those who insist that Boole's horizontal stroke is exactly equivalent to my accent express in his notation the complex equation

$$
(x=y)^{\prime}=(x: y)^{\prime}+(y: x)^{\prime},
$$

and explain its meaning clearly without departing from Boole's quantitative interpretation of his symbols.

Lastly, my symbol : expresses implication or inference, and does not, therefore, exactly coincide in meaning with Prof. Peirce's symbol of inclusion $-<$, as defined by him in his "Logic of Relatives," published in 1870. This symbol of inclusion, as I understand Prof. Peirce's definition of it, is simply equivalent to the words "is not greater than," and is therefore restricted to number and quantity. It is true that Prof. Peirce in his recent memoir on the "Algebra of Logic" extends the meaning of this symbol of inclusion, so as to make it also convey the same meaning as my symbol of implication; but as this memoir was published subsequently to my second and third papers in the Proceedings of the Mathematical Society, to which Prof. Peirce explicitly refers in his memoir and accompanying circular note, this later definition does not bear upon the point in discussion.

Prof. Jevons objects to my $\alpha: \beta$ as an abbreviation for $\alpha=\alpha \beta$, because he thinks it obscures the real nature of the reasoning operation. But one might with equal justice object on the same grounds to $\alpha^{3}$ as an abbreviation for $\alpha \alpha \alpha$, or to the left side of the equation in the binomial theorem as an abbreviation for the right side. The symbol $\alpha: \beta$ is the exact equivalent of $\alpha=\alpha \beta$, just as $\alpha=\beta$ is the exact equivalent of $(\alpha: \beta)$ $(\beta: \alpha)$, and I do not see that I create any obscurity by adopting in any investigation, and at any stage of the investigation, whatever form seems most suitable for the immediate purpose in view. But whether I am right or wrong in this opinion can only 